\title{
An Ever-Present Past: Didier Daeninckx and the Manouchian Resistance Group
}

'Writing is always "against"! [...] Personally, I am against authority and the disappearance of memory' — Didier Daeninckx (1997: 68) ${ }^{1}$

November 1943. Following a series of highly visible attacks in Paris, committed by the Communist, 'immigrant' Resistance group of Missak Manouchian, ${ }^{2}$ the Brigades spéciales (special Brigades) of the French police finally pounce on the perpetrators, and arrest follows arrest. At the end of a very brief trial a few months later, twenty-three members of the combat unit, including Manouchian himself, are condemned to death. The twenty-two men are immediately shot at Mont Valérien, on 21 February 1944 (the one woman, Olga Bancic, is executed separately, beheaded in Stuttgart on 10 May). More or less simultaneously, the photos of ten of these freedom fighters are displayed on the infamous Affiches rouges (red posters), which are plastered over the walls of French towns and cities, and which denounce 'l'Armée du crime' (the Army of crime), most obviously composed of people with names of foreign, if not Jewish, origin. Shortly afterwards, the Liberation of France, for which these combatants willingly gave their lives, commenced.

That is by no means the end of their story, however. Throughout the post-war period, the group regularly comes back into the headlines, forming, as Margaret Atack has noted, 'an important focal point for remembrance and controversy' $(2013: 175){ }^{3}$ For example, in 1955, in honour of the group, and to mark the inauguration of a rue du Groupe Manouchian in Paris, Louis Aragon writes the poem which will first appear in L'Humanité on 5 March 1955, entitled 'Groupe Manouchain', and then in his collection, Le Roman inachevé, as 'Strophes pour se souvenir' (1956: 225-26). Having been put to music, these 'strophes' reappear in 
1961 as 'L'Affiche rouge', the first track on Léo Ferré's LP, Les Chansons d'Aragon. Another important development occurs in the 1980s, when a 'Manouchian Affair' blows up, centred on allegations that the unit was deliberately sacrificed, and the ensuing debate runs and runs (Courtois, 1985; Kidd \& Blyth, 2000; Atack, 2013: 176-77). The 1980s also see the first of a number of books memorializing his former colleagues by one of the surviving members of the unit, Arsène Tchakarian $(1986,1991,2012)$.

Yet of all the writers and creative talents who focus on this 'Army of crime', one particular figure currently stands out in France. The figure in question is Didier Daeninckx. A prize-winning novelist and short-story-teller who now regularly publishes in mainstream collections, Daeninckx initially made his name in the noir genre, which provided him with the perfect outlet for his own version of the anti-establishment views that had run in his family for generations: his father and paternal grandfather were both anarchists, the latter having been punished for desertion in 1917, while his mother was a member of the PCF (French Communist Party), as was her father, the communist mayor of one of the Paris suburbs in the 1930s. Daeninckx similarly began his political life in the Party, but left in 1982, following a disagreement — an early example of his irrevocably contestatory spirit (Daeninckx, 1997: 8-9, 104-05, 117-19; Maricourt, 2009: 18-24, 262-63).

This all-embracing, politicized non-conformism continues to energize Daeninckx's writing today, and his œuvre is replete with 'rebellious characters, $[\ldots]$ characters who show that it is possible for things to change' (Maricourt, 2009: 218). It therefore comes as no surprise to discover that, time and again in recent years, the author has turned his gaze back to the Manouchian resistance group, and depicted it — to a greater or lesser degree — in a wide variety of his texts. It is the threefold aim of the present article to examine this apparent compulsion of Daeninckx's, to situate it in its broader context, and to suggest what it may reveal about the status of the Occupation in France today. 
Daeninckx's interest in the so-called 'Army of crime' first materializes in 2004, although its focus is not the obvious one. Rather than the leader, the centre of attention is another member of the group, Rino Della Negra. Daeninckx makes this footballer-for-Red Star-cum-doomed-Resister the subject of a brief biographical piece — later reproduced in $L a$ Mémoire longue (Daeninckx, 2008) — as well as the hero of Viva la liberté, the third of his Trois secrets d'Alexandra, a collection of illustrated children's books, all of which centre on the Occupation (2003a, 2003b, 2004). ${ }^{4}$ The following year, Della Negra reappears in 'Rubrique Sports', one of the short stories in Cités perdues, and then in 2006, he resurfaces again, this time with his comrades-in-arms, in Itinéraire d'un salaud ordinaire. Spanning the period from 1942 to 1981, but devoting about half of its pages to the Occupation and its immediate aftermath, this lengthy (for Daeninckx) novel follows the salaud ordinaire (ordinary bastard) of the title as he moves up the ranks, progressing from his early subordinate role in the wartime Special Brigades to his more active participation in many of France's post-war causes célèbres prior to 1981. Although the Manouchian group's appearance here is limited, the text is an important part of the overall story, as it deals at some length with the policemen who effected the arrests, giving readers an excellent insight into the outlook and practices of these detectives.

The significance of this focus becomes clear in 2009, when Missak appears. In this novel set in the winter of 1954-55, Louis Dragère, a young journalist at L'Humanité and a committed member of the PCF, is asked to conduct a review of the Manouchian group, so that the party will know if there are any skeletons in the cupboard of this now-lauded team of men and women (the man who explains the task is the suggestively named Vieuguet - Old lookout). In time-honoured detective fashion (despite the fact that the book is not marketed as belonging to this genre), Louis embarks on an investigation, by the end of which a detailed portrayal of Manouchian, the Armenian poet who ended up dying for France, has emerged. 
Given its subject matter, then, Missak can be seen as the perfect complement to Itinéraire d'un salaud ordinaire. Its concentration on the eponymous Resistance leader combines with the earlier work's depiction of his enemies to form a far more complete and balanced picture. What is more, as Daeninckx himself has admitted, nothing could better offset 'the itinerary of an ordinary salaud' than 'that of an exemplary hero' (Rubino, 2009: 178). ${ }^{6}$

Still in 2009, Daeninckx publishes a second version of the Manouchian narrative, Missak, l'enfant de l'Affiche rouge, a text which, like Viva la liberté, is illustrated and aimed at young children. In 2010, a third variation on the theme appears, this time for slightly older children. Entitled Avec le groupe Manouchian, it once again has Rino Della Negra amongst its cast list. Finally, in 2012, Daeninckx's Goncourt-Prize-winning collection of short stories, L'Espoir en contrebande, includes two further references to members of the group: the ubiquitous Della Negra features briefly in 'Fous du Foot', while Manouchian plays a more fundamental role in 'Page de garde'.

All of this evidence ably demonstrates that, since the start of the new millennium, Daeninckx has been obsessed by the Manouchian group, but what might his motivation be? Apart from the range of narrative possibilities that the combat unit offers to an established writer of noir fiction, there are a whole host of other answers to this question, one notable one being the need to provide a personal commemoration in print, to honour the commitment, rebellion and ultimate self-sacrifice of these brave freedom fighters. This tribute can be seen in many ways. Firstly, the titles of the key works, which convey a positive intimacy with the leader of the gang (he is affectionately called Missak) or a bond of solidarity with all of its

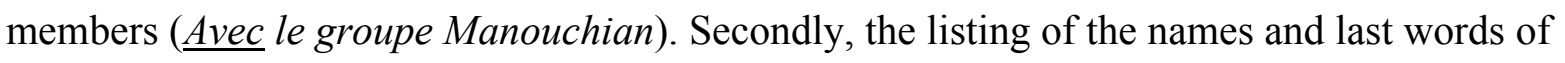
those involved, as is best seen in Avec le groupe Manouchian (2010: 93-94, 100-101), where the now grown-up narrator takes part in television and radio debates, explicitly explaining, in words reminiscent of those of the 'Father of History', Herodotus: 'I remember their names 
[...]; by speaking I save them from oblivion at least' (2010: 99). ${ }^{7}$ Finally, there is perhaps a more subtle accolade being offered by Daeninckx, and this to Manouchian in particular. Speaking of Missak, ou l'enfant de l'Affiche rouge, Hélène Le Bon has observed: 'History is rewritten as a poem, in homage to the poet that Missak Manouchian was when he was alive' (Le Bon, 2010: 213). The same 'poetic' quality is a feature of all of Daeninckx's fictions on this subject, with Missak being a conspicuous example.

The start of this novel sees Louis and his photographer travel to meet a gang of local youths, the Fauch'man, so called because of their lack of money (fauché = 'broke'), on whom he is to write an article. The encounter is eloquent. Margaret Atack has rightly highlighted the way in which 'an obvious parallel is drawn with the foreign resisters', thanks to their camaraderie, their nicknames, their marginality, and the fact that their photos will soon be displayed for all to see (Atack, 2013: 179), but the resonance does not end there. The access to the teenagers' den is via a sort of small, concealed basement window, and once Louis is inside, an electricity cut makes the scene look like 'a meeting of conspirators' (Daeninckx, 2009a: 17). Here, too, the opening serves as a metaphorical introduction to the narrative to come, for Dragère will soon be asked to go on another journey, down into a more or less hidden past, to investigate and write about another group of young conspirators working in the shadows (those of the 'dark years' of 1940-44). Indeed, the Manouchian group could almost also be called the Fauch'man, given that another meaning of the French verb faucher is 'to mow down'.

After this suggestive opening, further 'poetic' devices of all kinds regularly follow. Another metaphor is in evidence when, on his way to a meeting at which he might somehow be at risk, Louis passes a statue of Little Red Riding Hood (2009a: 128). The figure obviously comes to represent him: naive and politically 'red', he too has his (ideological) innocence threatened by the 'wolf' he encounters, learning that one of Manouchian's comrades-in-arms 
seems to have been 'a Trotskyite mole who had infiltrated the most prestigious group of Communist fighters' (2009a: 130). In addition to such metaphors, Missak is characterized by a network of echoes and leitmotifs. Louis's is not the first internal investigation of its kind (2009a: 241, 254); information is frequently repeated, as interviewees say the same things and Louis writes down, and then transcribes, what he has heard; and there are two betrayals of the group, which are in turn mirrored by the situation of all those members whom the Communist Party has recently denounced and punished as traitors, the Resistance hero, Charles Tillon, included (2009a: 123, 171-72, 173, 190-91. Cf. Daeninckx, 1997: 109). An important variation on this strategy of repetition is the use of mises en abyme. For instance, reflections of Manouchian are seen both in the artist Bediguian's portrait of him (2009a: 89$90),{ }^{8}$ and in the quotations from Victor Hugo's poem 'L'Enfant' (2009a: 148-50), which depicts a young Greek boy 'abandoning all the beauties of the world for gunpowder and bullets' (2009a: 150 - Daeninckx's italics). There are also oft-repeated commemorations within Daeninckx's own literary commemoration, most notably the references to the forthcoming inauguration of the rue du Groupe Manouchian in Paris and to Aragon's aforementioned memorial poem, written to mark the event. ${ }^{9}$

All of these various homages come together in a crescendo at the end of the novel, after Louis submits his positive report. The new street is inaugurated; Aragon's poem appears; the key figures whom Louis has interviewed are present; and the assignment on the Fauch'man is completed. Now, although this finale clearly gestures (once again) to the traditional detective novel, where after a period of disruption and an admittedly conclusive, linear investigation, things finally return to normal, it does something more besides. The circularity involved here — and throughout — provides another 'poetic' tribute to Manouchian, structurally mirroring the life of the man who escaped deportations, concentration camps and genocide in Armenia (2009a: 56-58), only to find the Nazis doing 
the same thing in Europe, and who, Daeninckx stresses, was executed the day before his wedding anniversary (2009a: 98).

At least part of the significance of Daeninckx's individual obsession with Manouchian and his colleagues is that it is part of a much broader commemorative thrust. In February 2004, the sixtieth anniversary of the executions was remembered at a ceremony at Mont Valérien, while Rino Della Negra's football club, Red Star, unveiled a plaque in his honour before the team went on to play — significantly given the group's links to that part of the world - l'Arménienne (the Armenian team). Daeninckx attended this match (Allezredstar, 2004; Maricourt, 2009: 179), and was clearly inspired by the event as it serves as the narrative present in Viva la liberté. These two celebrations were quickly followed by a mass of others, and in a variety of areas. In 2009, the book-reading public could not only enjoy Daeninckx's Missak and Missak, l'enfant de l'Affiche rouge, but also Alain Blottière's Le Tombeau de Tommy (which focuses on another important member of the Manouchian group, one who likewise traverses Daeninckx's texts on the subject: Thomas Elek). In the area of the visual arts, Robert Guédiguian's controversial film, L'Armée du crime (2009) undeniably stands out, but other noteworthy developments include the DVD release of Frank Cassenti's 1976 movie, L'Affiche rouge (2008), and the appearance of two documentaries: Amat and Peschanski's La Traque de l'Affiche rouge (2006), which aired on television on 15 March 2007, and Michel Ionascu's Missak Manouchian, une esquisse de portrait (2012), to which Daeninckx contributed, and which toured a number of community arts centres. In a different branch of the visual arts, a huge painting of Manouchian on the side of a building in Paris was unveiled (March 2012), and although it was later to be defaced with racist graffiti (Le75020, 2014), this actually served to keep its subject in the news. At the same time as all of these tributes were taking place, the succession of more formal, public commemorations continued. On 21 February 2009, a plaque was unveiled at 11, rue de Plaisance in Paris, to 
mark the site where Manouchian and his wife last lived, while an indirect homage was made on 8 March 2012, when the aforementioned Arsène Tchakarian was made an Officer of the Legion of Honour for his work on the group, with President Sarkozy making clear precisely what the individual author's contribution to the nation (and, implicitly it might be said, the contribution of all of those mentioned here) amounted to: 'Memory is the writing of your books' (Tchakarian, 2012: 298). More recently, in February 2014, seventy years after the executions, Red Star, which has regularly organized commemorations, again celebrated the life of Rino Della Negra, while there was another ceremony at Mont Valérien, attended by dignitaries such as President François Hollande and Charles Aznavour, whose own family is part of the Manouchian story, and whose fame - like the Red Star football matches — has helped to keep it alive in popular culture. Currently, there is a campaign to get the ashes of those executed transferred to the Panthéon, the ultimate accolade. Needless to say, Daeninckx is one of the signatories of the on-line petition (Manouchian-panthéon, 2014).

If this broader context shows that Daeninckx is very much in tune with, if not slightly ahead of his time, as he has been ever since his break-through novel, Meurtres pour mémoire $(1983),{ }^{10}$ this is not to say that he has abandoned his role of rebel and militant activist. On the contrary. By praising the Manouchian group, he is able, as is his wont, to underline the longneglected contribution made to France by non-natives. It is not for nothing that the sub-title of Avec le groupe Manouchian is Les Immigrés dans la Résistance (Immigrants in the Resistance), ${ }^{11}$ nor that, within its pages, when a unit of soldiers from the collaborationist LVF (Legion of French Volunteers against Bolshevism) marches past, one of the Resisters says: 'We, who were born in all four corners of the earth, in Hungary, Armenia, Poland, Romania, [...] we are doing more for this country than those loud-mouths on parade protected by their masters...' (2010: 32-33). Yet Daeninckx is not simply making a point about the Occupation here. As ever (see Maricourt, 2009: 212, 214, 217), he believes that the past is relevant to the 
present - a connection already implicit in his use of the Fauch'man metaphor in Missak and that racism, anti-Semitism and fascism live on, and still need to be countered. This is why, in his various texts on the Manouchian group, he includes quotations from the extreme right-wing press of the time. This is why, in the Epilogue of Avec le groupe Manouchian, he has his now-adult narrator say:

It will soon be seventy years since the gunshots rang out over the hill at Mont Valérien, but not a single day has passed since without me trying to prolong the echo. To warn of the danger. (2010: 99)

This is also why, in the same book (2010: 38-40), the blowing up of a pro-Nazi bookshop (by Thomas Elek) by means of a book bomb has great symbolic value - it represents the explosive power of literature and the ability to use it as a weapon, ${ }^{12}$ qualities that the author himself exploits to denounce the threats he sees around him.

One way to combat this menace is, of course, to make sure that everyone is aware of it. This, too, is part of Daeninckx's project — to inform (cf. Maricourt, 2009: 274). Thus, in Missak, details are given of a number of things about which, it is stated, 'nobody speaks', including the role of women in the Resistance and two executed Resisters, Georges Gruman and Maurice Brover (2009a: 91 \& 169; 213 respectively). It is on Manouchian himself, however, that Daeninckx claims to shed most new light, thanks largely to his discovery of, in his own words, 'a number of unpublished documents, of which the historians were unaware' (Daeninckx, 2009c: 153. Cf. Rubino, 2009: 179-80).

This wish to enlighten, this attempt to bolster memory and to use his writing 'to counter oblivion' (Maricourt, 2009: 211) leads Daeninckx to accompany his tribute to the Manouchian group with a whole host of unsavoury facts from the Occupation. Some are presented at length, others only in passing, but the cumulative effect is striking. Most visibly, perhaps, he reminds his readers that the French special Brigades arrested Manouchian and his 
colleagues, engaged in torture and generally acted dishonourably (in Itinéraire d'un salaud ordinaire, there is ironic reference throughout to the 'cour d'honneur' — the central courtyard, literally the 'courtyard of honour' — at the Paris police headquarters). He also recalls other collaborators, of varying commitment and motivation: the French volunteers of the LVF, the SS Charlemagne Division, the Milice (Militia), and the French Gestapo; the judges; and the senders of the 'millions' of letters of denunciation. At the same time, he turns the spotlight onto France's persecution of Jews - pointing out that they were sometimes betrayed by their own co-religionaries (2006: 47-49; 2009a: 91) — and highlights a number of eloquent events linked to the Liberation, such as the failure properly to purge those who had compromised themselves, a failure which is of course linked to his current warnings about neo-Nazism.

The Resistance, and specifically the Communist Resistance, does not escape Daeninckx's admonishing gaze either. In Missak, as mentioned earlier, the 'Army of crime' is revealed to be riven by factionalism and betrayed by its own members twice, while the PCF's move, in the course of the Occupation, from non-belligerence to full-blown guerrilla warfare is shown massively to complicate the moral landscape. In fact, as is so much else, this breaking down of simplistic, black-and-white certainties is embodied by the Manouchian group itself, for it included a German (an antifascist, and an inverted mirror image of the Frenchmen who fought for Hitler), and its leader was a poet-warrior, an intellectual man of action (as too is Daeninckx).

Daeninckx's attempt to underline the complexity of the Occupation for his readers goes hand in hand, quite naturally, with a recognition of some of the problems involved in trying to recover the past. In Missak, the information that Louis accumulates is often contradictory (2009a: 185), the recollections of eye-witnesses are unreliable (2009a: 110), and to make matters worse, there are Machiavellian forces at work. 'Memory can often be 
seen to be organized forgetfulness', Henry Rousso has observed (1987: 14), and Paul Ricoeur has similarly highlighted 'the abuses [...] resulting from a concerted manipulation of memory and forgetfulness by those in power' (2003: 97). This is precisely what Louis discovers — the references to betrayal which are in Manouchian's final letter have mysteriously disappeared from the transcripts prepared by the PCF (2009a: 185). Then there is the problem of writing about the past, a problem encapsulated by Daeninckx's own preference for historical fiction, where the boundary between history and invention is blurred. Undeniably, much of the author's work for and in Missak is that of a historian. He has conducted research, consulted archives and eye-witnesses, discovered new documents, and then published the results, portraying historical figures, reproducing source material, and including a bibliography. ${ }^{13}$ Yet the paratext insists that this 'densely referential text' (Atack, 2014: 277) is a novel, and this assertion is fully justified within its pages, for just as Louis's investigation represents the PCF's looking in on itself, so too is this text blatantly self-aware (cf. Atack, 2013: 176, 181). A good example of this is its central portrayal of the writing process - writing as investigation, writing as re-writing — as Louis amasses the details that eventually inform his report. Furthermore, the large role played by literature and quotation (as shown by Hugo's aforementioned poem) is impossible to miss, ${ }^{14}$ as is the citing of the associated creative arts of film, painting and song (cf. Daeninckx, 2010: 8). Throw into this mix Daeninckx's many mises en abyme, as demonstrated earlier, and what we have here is a form that underlines the interrogative nature of the text. Are historical and literary narratives really all that different? Is a divide between the intra- and extra-textual worlds actually relevant to literature? How much confidence can people have in official memory, in official history, or even in archives? These are just some of the questions that Daeninckx is asking (see also Atack, 2013).

He is also asking questions about identity. Speaking of his own works decades after the Liberation, the winner of the Nobel Prize for Literature in 2014, Patrick Modiano, 
admitted: 'For me, many of the historical figures cited are almost characters from legends. I feel as if they are some sort of myth' (Montalbetti, 1969: 43). Daeninckx, in Missak, seems to be in a similar situation, very much aware that Manouchian is not so much a man as — just like the Greek boy in Hugo's poem which evokes him — a linguistic construct, or to reapply Atack's comment on the whole group, 'a product of narrative and ideological processes' (2013: 177). During the Occupation, the rebel leader became a criminal, a bogey-man, this identity forged for him by l'Affiche rouge and collaborationist journalists. Then after the war, he became an exemplary Resister, an idealized icon of the PCF, as vaunted, along with his group, in Aragon's poem.

It is the simplification of this second myth that is the major cause of concern for Daeninckx. 'The statue erected in his honour puts the hero in the shade', the novelist has lamented (Rubino, 2009: 181), and the self-same worry is equally evident in Missak, as expressed via one of its key leitmotifs — the rising level of the Seine and associated flooding, which result in the gradual disappearance into the river of the statue of the Zouave on the Pont de l'Alma (Alma bridge). The Zouave, of course, is a foreign French fighter, just like Manouchian, and the allusive threat posed is made clear when the army has to move things out of the cellars of Notre-Dame, the storerooms of the Louvre and the archives of the PalaisBourbon 'so that the memories stored underground [...] are not swamped' (Daeninckx, 2009a: 213). ${ }^{15}$ Daeninckx is engaged in similar salvage work. ${ }^{16}$ As suggested by his use of metaphors - another example of self-aware mirroring — he wants to get to the story beneath the surface story, 'to scratch away to see what lies behind, to give free rein to the power of memory' (Maricourt, 2009: 71). He wants to combat the idealized myth, to paint a more complex picture of Manouchian and 'give a new and surprising dimension to [his] character' (Daeninckx, 2009c: 153), to give him back his humanity, his identity, and thereby provide him with the tribute he merits. In so doing, he can simultaneously mount a more general 
attack, and denounce the 'instrumentalis[ation of] the heroic sacrifice of the Resistance' that had become such a striking feature of the presidency of Nicolas Sarkozy (Raymond, 2013: 99 and passim), and of which he would have been all too aware when he was writing Missak and its companion volumes.

The preceding analysis would seem to suggest that, in many ways, a useful reference point for Daeninckx's personal and, often, the more widespread, obsession with Manouchian is given by Pierre Nora's celebrated Lieux de mémoire (1984-92) and his innovative concept of the realms or sites of memory. Defined broadly to encompass both the concrete and the abstract, these 'symbolic element[s] of the memorial patrimony of any community' (Nora, III.1 (1992): 20) are closely linked to all acts of commemoration, so much so that the final section in the whole work is devoted to what Nora considers to be - not without annoyance — 'the era of commemoration' in which he finds himself (III.3 (1992): 975-1012). Whether Nora intended his study to be limited to his own time or not (III.3 (1992): 1012), the fact remains that the Manouchian group now appears to have become another, albeit contemporary, 'site of memory' in France. ${ }^{17}$

Apart from this fundamental relevance, there are further ways in which Les Lieux de mémoire resonate with the current trend of paying homage to 'the Army of crime', and especially with Daeninckx's approach. Like Daeninckx, in addition to memory, Nora is concerned with French history — one of his chapters is entitled 'How should the history of France be written?' (III.1 (1992): 9-32). Again like Daeninckx (see Maricourt, 2009: 211), he is also interested in the 'traces' left by an event or a person (III.1 (1992): 24-25), and with the import of the past to the present: every commemoration, he writes, embodies 'the awareness of distance and the wish to abolish it' (III.3 (1992): 979). Finally, the new form of remembrance that Nora discerned is patently the one to which Daeninckx and his fellow commemorators now lend their weight: 'the subversion and disintegration of the classic 
model of national commemoration $[\ldots]$, and its replacement by a fragmented system, composed of disparate commemorative languages and predicated upon a different relationship with the past, one that is chosen rather than imposed' (III. 3 (1992): 983-84). ${ }^{18}$

Yet in spite of these links, Les Lieux de mémoire does not provide a perfect paradigm for the commemorative trend examined thus far. For one thing, Nora suggests that history and memory are completely separate (III.3 (1992): 1006), whereas Daeninckx's work assumes a symbiotic relationship between the two. What is more, a key element of Daeninckx's fiction is the revelation of unsavoury details about the Occupation, but Nora himself posits that this might be a weakness of his own work when he rehearses some of the possible criticisms of his previous volumes in his final tome: amongst the things not dealt with, he notes, is 'everything France represses and does not want to know about itself' (III.1 (1992): 19). In his analysis of a different novel by Daeninckx (Le Der des ders), centred on a different conflict (World War I), Martin Hurcombe demonstrates how the novelist overcomes 'the binary opposition of history to memory, incorporating a pluralising, contestatory memory that enriches our historical understanding of the war, revealing previously occluded aspects of its politically complex reality, thereby undermining a monolithic post-war narrative of national unity' (2014: 13). The same applies to the author's Manouchian project, and it is no doubt at least partly because of this 'pluralising' heretical impulse — and probably also because of fiction's greater ability to handle the sort of unreliable, contradictory and often fragmentary information referred to earlier — that Daeninckx has chosen to write novels, albeit historical novels, rather than histories à la Nora.

Before concluding, it will be helpful to consider one final aspect of Daeninckx's Manouchian project — the importance of different generations. In Missak, Louis is a young man in 1954-55, and was still in his mid-teens when the war ended. Aliona, the narrator of Avec le groupe Manouchian, is even younger during the Occupation, when the main narrative 
is set. In both cases, there is a marked parental absence (2009a: 84, 217, 154-55; 2010: 5, 14$15,38,55)$, and what this equates to is clear: a young generation cut off from its roots and lacking a heritage, as symbolized by the missing parents. ${ }^{19}$

In her recent study of French crime fiction and the Second World War, Claire Gorrara has spoken of this self-same problem of a lack of transmission of the past, and recognized the role of children's crime books — and indeed Daeninckx's children's books — in any attempt to solve it (Gorrara, 2012). Although the works in question here cannot, for one reason or another, assuredly be classified as crime fiction, provide a remedy is precisely what Daeninckx is trying to do. His two children's books on Manouchian include a range of paratextual support - an interview, photographs, reproductions of letters, and so on - to reinforce the impact of the actual narratives. They are nothing if not well documented. ${ }^{20}$ In this light, the very end of Missak is revealing. Part of the positive conclusion that has already been described is the return of Louis's previously absent mother, a sign that, now that his investigation into the Manouchian group is over, at least part of his, and by extension the nation's, lost heritage and identity has been restored. However, quite apart from the sense of circularity generated and the other non-totalizing literary techniques already mentioned, the complete story has not been told. Louis has not met up with all of the key witnesses, and what really happened remains, to his mind, a jigsaw with pieces missing, so much so that he readily admits that he has not understood everything (2009a: 273, 278). This sense of unresolved business remaining — which in turn reflects Daeninckx's general distrust of official consensus and memorial closure - is much more noticeable in the Epilogue to Avec le groupe Manouchian, where the now grown-up Aliona reveals that she is still going into schools to talk about her experience of the Resistance, in much the same way as Daeninckx, in a further blurring of boundaries, extends his work to teenagers and young children. 
This is worthy of note. The widespread reassessment of the Occupation that emerged in France in the 1970s, dubbed the mode rétro (retro fashion), showed that this problem of the transmission of knowledge about the war years, with all of its implications for individual and national memory and identity, badly affected the younger war and post-war generations the generations of Louis, Aliona, and indeed Daeninckx himself (he was born in 1949). Yet forty or so years later, another one or two generations further on, the battle for hearts and minds is evidently still being fought, and it is in this context that the existence of one, final metaphor might be suggested. Insofar as the Manouchian group is a collective made up of individual parts, occasionally marked by betrayal, anchored in both the past and the present, and open to manipulation by people in positions of power, would it be wrong to see it as a sort of embodiment of memory in the abstract, the implicit subject of Daeninckx's investigation?

To conclude, as may by now be clear, Daeninckx's Manouchian project expresses itself over a number of years, in a variety of formats, and with different target audiences. What appears to motivate him, besides the basic, understandable wish to tell a good story, is a mixture of inter-related drives. He wants to commemorate the freedom fighters concerned; praise, through them, the contribution made by non-natives to France; show — and warn his compatriots — that the problems posed by the war have not gone away; give a more rounded picture of the Occupation in general and of Missak Manouchian in particular; and counter the ongoing political exploitation and misrepresentation of the Resistance. In doing this, he additionally raises questions about literature, history, recollection, and the recoverability of the past, targeting especially the young, in an attempt to increase their knowledge of the war years and, despite the obvious difficulties involved, bolster their, and the nation's, identity. This quest, as may by now also be clear, takes on a distinctive form. Prime amongst Daeninckx's narrative strategies — both within his individual, often interrogative texts and 
sometimes between them — are metaphor, repetition, circularity, intertextuality and mise en abyme. Indeed, such mirror-play can even be seen on a far broader level, with the author's Manouchian project representing a microcosm of the wider concern with the combat unit. ${ }^{21}$ What this ultimately suggests, of course, is a lack of finality, as any one narrative tends to lead on to something or somewhere else. This is important, and not merely because it further reflects Daeninckx's disaffection with officialdom's pursuit of resolution. Given that his personal venture is also a smaller version of the fascination with the dark years of 1940-1944 in general, his refusal of easy closure may be extrapolated to this much higher level as well, and taken (along with his choice of subject matter) as another (if more evocative) sign of the phenomenon that John Flower has recently analyzed so well (2014) — the fact that the country is still, as it were, locked in the circle of remembrance, still plagued by 'the tyranny of memory' (Nora, III.3 (1992): 1012); that it is still awaiting its final liberation from the Occupation; and that the words of Conan and Rousso, expressed way back in 1994, still palpably ring true: France continues to be in the grip of 'un passé qui ne passe pas', a naggingly indigestible, 'ever-present past' (Conan \& Rousso, 1994, 1998). ${ }^{22}$ 


\section{Works Cited}

Unless otherwise indicated, all books listed are published in Paris.

L'Affiche rouge. 2008. Directed by F. Cassenti [DVD]. Doriane films.

Allezredstar. 2004. Hommage à Rino Della Negra: La Presse (février 2004). [online]

[Accessed 23 January 2015]. Available at:

http://www.allezredstar.com/archives/fr_della4.htm.

Aragon, L. 1956. Le Roman inachevé. Gallimard.

L’Armée du crime (The Army of Crime). 2009. Directed by R. Guédiguian. Agat films/StudioCanal/France 3 cinéma.

Atack, M. 2013. Romans inachevés de l'Histoire et de la mémoire: les FTP-MOI et l'Affiche rouge. In: M. Dambre, ed., avec le concours de C. D. Lloyd et R. J. Golsan. Mémoires occupées: Fictions françaises et Seconde Guerre mondiale. Presses Sorbonne nouvelle, pp. 175-82.

Atack, M. 2014. From Meurtres pour mémoire to Missak: Literature and historiography in dialogue. French Cultural Studies, 25(3/4): 271-80.

Blottière, A. 2009. Le Tombeau de Tommy. Gallimard.

Bragança, M. 2014. Vichy, un passé qui ne passe pas?. French Cultural Studies, 25(3/4): 309-19.

Conan, É. \& Rousso, H. 1994. Vichy, un passé qui ne passe pas. Fayard.

Conan, É. \& Rousso, H. 1998. Vichy: An ever-present past, trans. by N. Bracher. Hanover, N.H./London: University Press of New England.

Courtois, S. 1985. Les Communistes et la Résistance. Le Nouvel Observateur, 28 June-4 July, pp. 26-28. 
Daeninckx, D. 1983. Meurtres pour mémoire. Gallimard.

Daeninckx, D. 1997. Écrire en contre. Vénissieux: Paroles d'aube.

Daeninckx, D. 2001. 12, rue Meckert. Gallimard.

Daeninckx, D. 2003a. Il faut désobéir. With illustrations by Pef. Voisins-le-Bretonneux: Rue du monde.

Daeninckx, D. 2003b. Un violon dans la nuit. With illustrations by Pef. Voisins-leBretonneux: Rue du monde.

Daeninckx, D. 2004. Viva la liberté. With illustrations by Pef. Voisins-le-Bretonneux: Rue du monde.

Daeninckx, D. 2005. Cités perdues. Lagrasse: Verdier.

Daeninckx, D. 2006. Itinéraire d'un salaud ordinaire. Gallimard.

Daeninckx, D. 2008. Rino Della Negra, le footballeur fusillé. In: D. Daeninckx. La Mémoire longue. Le Cherche Midi, pp. 339-41.

Daeninckx, D. 2009a. Missak. Perrin.

Daeninckx, D. 2009b. Missak, l'enfant de l'Affiche rouge. With illustrations by Laurent Corvaisier. Voisins-le-Bretonneux: Rue du monde.

Daeninckx, D. 2009c [2007]. Histoire et faux-semblants. Magnard.

Daeninckx, D. 2010. Avec le groupe Manouchain: Les Immigrés dans la Résistance. Oskarson.

Daeninckx, D. 2012. L'Espoir en contrebande. Le Cherche Midi.

Ferré, L. 1961. Les Chansons d'Aragon [LP]. Barclay.

Flower, J. 2014. A continuing preoccupation with the Occupation. French Cultural Studies, 25(3/4): 299-308

Gorrara, C. 2012. French Crime Fiction and the Second World War: Past Crimes, Present Memories. Manchester and New York: Manchester University Press. 
Herodotus. 1962. The Histories of Herodotus of Halicarnassus, trans. by H. Carter. London: Oxford University Press.

Hurcombe, M. 2014. Untold Crimes: The First World War and the Historical crime Fiction of Jean Amila and Didier Daeninckx. Modern \& Contemporary France [online] (17 April 2014) [accessed 22 January 2015]. Available at:

http://www.tandfonline.com/doi/full/10.1080/09639489.2014.904280.

Kidd, W. \& Blyth, A. 2000. Aragon, Léo Ferré et L'Affiche rouge. In: A. Macanulty, ed. Aragon, Elsa Triolet et les cultures étrangères: Actes du Colloque de Glasgow, avril 1992. Besançon: Presses Universitaires Franc-Comtoises, pp. 99-114.

Le75020. 2014. Un tag pro-Dieudonné souille la fresque hommage au groupe Manouchian. [online] [Accessed 23 January 2015]. Available at: http://le75020.fr/paris-XXe75020-20e-arrondissement/vie-locale/61757-tag-pro-dieudonne-souille-fresquehommage-groupe-manouchian.paris-75020-info.

Le Bon, H. 2010. D. Daeninckx et L. Corvaisier, Missak, l'enfant de l'Affiche rouge. Hommes et migrations [online] 1283 [accessed 22 January 2015]. Available at: http:/hommesmigrations.revues.org/1041.

Manouchian-panthéon. 2014. Pour le transfert des cendres du groupe Manouchian au Panthéon. [online] [accessed 22 January 2015]. Available at: http://manouchianpantheon.com/.

Maricourt, T. 2009, Daeninckx par Daeninckx. Le Cherche Midi.

Missak Manouchian, une esquisse de portrait. 2012. Directed by M. Ionascu. Zongo cinema. Montalbetti, J. 1969. Patrick Modiano ou l'esprit de fuite. Magazine Littéraire, November 1969, pp. 42-43.

Nora, P. ed. 1984-1992. Les Lieux de mémoire. 3 volumes. Gallimard. 
Raymond, G. Sarkozy-de Gaulle: Recycling the Resistance myth. French Cultural Studies, 24(1): 93-103

Ricoeur, P. 2003 [2000]. La Mémoire, l'histoire, l'oubli. Éditions du Seuil.

Rousso, H. 1987. Le Syndrome de Vichy: 1944-198... Éditions du Seuil.

Rubino, G. 2009. Lire Didier Daeninckx. Armand Colin.

Tchakarian, A. 1986. Les Francs-Tireurs de l'Affiche rouge. Messidor/Éditions sociales.

Tchakarian, A. 1991. Les Fusillés du Mont-Valérien. Nanterre: Comité national du souvenir des fusillés du Mont-Valérien.

Tchakarian, A. 2012. Les Commandos de l'Affiche rouge. Monaco: Éditions du Rocher.

La Traque de l'Affiche rouge. 2006. Directed by J. Amat \& D. Peschanski. France 2 Television, broadcast 15 March 2007. 


\footnotetext{
${ }^{1}$ Here and throughout this article, all translations from the original French are my own.

${ }^{2}$ The fighters belonged to the FTP-MOI, the Francs-Tireurs et Partisans-Main-d'œuvre immigrée (Francs-
}

Tireurs and Partisans-Immigrant workers). As Daeninckx (2010: [112]) and Courtois (1985: 26) point out, there was strictly speaking no 'Manouchian group' as such; the term is used as a convenient shorthand reference.

${ }^{3}$ I am grateful to Professor Claire Gorrara for bringing this article to my attention.

${ }^{4}$ The second of these three books is dedicated to a certain Henri, who, as Daeninckx has revealed (Maricourt, 2009: 207), is actually Henri Krasucki, another member of the Manouchian group.

${ }^{5}$ Daeninckx helpfully explains the epithet he uses for his protagonist: 'A salaud is someone who does not think. Their job has replaced their conscience. [...] My collabo character is ultimately unexceptional. He has family problems and trouble finding food to eat. I wanted to show that torturers are part of the real world' (Maricourt, 2009: 199). The same Special-Brigader briefly reappears in the later short story 'Mères glorieuses, mères angoissées' (see e.g. Daeninckx, 2009c: 42-43).

${ }^{6}$ The two novels contrast with each other in many other ways besides. For example, Louis, in Missak, is a journalist, whose job, it is stated (2009a: 80), is to reveal the truth, whereas the protagonist of Itinéraire d'un salaud ordinaire initially works in the 'lies and fibs' section, manipulating the diffusion of information. This latter text also depicts a real-life member of the French Gestapo, Alex Villaplane, who was a former French international footballer; he therefore serves as a sort of inverted image of the footballing Resister, Rino Della Negra.

${ }^{7}$ Herodotus writes: 'Here are set forth the histories of Herodotus of Halicarnassus that men's actions may not in time be forgotten nor things great and wonderful, accomplished whether by Greeks or barbarians, go without report' (1962: 2).

${ }^{8}$ This is even more pronounced in Missak ou l'enfant de l'Affiche rouge, where one of the illustrations shows an artist in the process of sketching Manouchian, so there is a double, not a single, pictorial representation.

${ }^{9}$ It was, in fact, precisely these tributes which caused Daeninckx to set his novel in the winter of 1954-55 (Rubino, 2009: 181).

${ }^{10}$ See e.g. Maricourt, 2009: 215, 220.

${ }^{11}$ Similarly, the documentary section at the end of Missak, l'enfant de l'Affiche rouge is entitled 'Missak Manouchian et les immigrés résistants de l'Affiche rouge' (Missak Manouchian and the immigrant resisters on the Affiche rouge).

${ }^{12}$ Cf. Daeninckx, 2006: 233-37 (although the book bomb here is used during a later conflict, and to typically more ironic effect).

${ }^{13}$ Itinéraire d'un salaud ordinaire likewise contains a bibliography, while Avec le groupe Manouchian and Missak, l'enfant de l'Affiche rouge, for their part, contain a variety of paratextual documentation.

${ }^{14}$ Cf. Daeninckx, 2010: 19, 22, 45, 53, 59, 81. Note also the self-reference in this text - the narrator has to go to 12, rue Meckert (2010: 92), which is the title of one of the author's other novels (2001).

${ }^{15}$ There is a little clue within the narrative itself that the Zouave (like Little Red Riding Hood) operates on a second, more evocative level: the reference to the Gare du Nord and its 'statues symbolizing the cities of Europe' (2009a: 153 - my italics).

${ }^{16}$ Note that Dragère lives in the rue de l'Aqueduc (Aqueduct Street), as befits his role in channelling the metaphorical waters away.

${ }^{17}$ Cf. Nora's comment on the 'contemporary [in the early 1990s] commemorations that have now become "sites of memory"' (III.3 (1992): 978).

${ }^{18}$ In addition to the similarities given above, note Nora's insistence that 'in France, commemoration is on the political left' (III.3 (1992): 1001). The commemorative drive would therefore be natural for the militant Daeninckx.

${ }^{19}$ Daeninckx has admitted: 'One of the themes of all of my books is the vagueness of people's identities, the uncertainty of their origins, and the fragility of family ties' (Maricourt, 2009: 90-91). This concern with notions of heritage and identity provides another obvious link to Nora.

${ }^{20}$ It is, of course, Daeninckx's use of a variety of genres - teenage fiction and illustrated children's books, as well as novels and short stories - that allows him to exploit a range of documentation and achieve maximum impact.

${ }^{21}$ These Russian-doll effects again highlight the links to Nora. Note, for instance, the historian's assertion that his Lieux de mémoire venture 'has become [...] a "site of memory" in its own right' (III.1 (1992): 11). Cf. Nora, 1992, III.1: 18 and III.3: 978, 980.

${ }^{22}$ The day of deliverance may, however, be not too far away - see Bragança, 2014. More broadly, considering that, in his œuvre as a whole, like many other contemporary French novelists, Daeninckx does not restrict himself to the dark years of the 1940s, but extends his explorations to a range of troublesome periods of French 
history - World War I and the Algerian War amongst them - it might well be argued that both he and France are in thrall to the, rather than to an, ever-present past. It is a topic that could usefully be explored. 